\title{
PEMANFAATAN TEKNOLOGI INTERNET OF THINGS UNTUK MONITORING TAMBAK UDANG VANAME BERBASIS SMARTPHONE ANDROID MENGGUNAKAN NODEMCU WEMOS D1 MINI
}

\author{
Saeful Anwar ${ }^{1}$, Abdurrohman $^{2}$ \\ 1,2Teknik Informatika, Universitas Sangga Buana YPKP \\ ${ }^{1}$ Saefulanwar1994@outlook.com, 2abdur@inti.co.id
}

\begin{abstract}
ABSTRAK
Udang vaname (Litopenaeus vannamei) adalah jenis udang introduksi yang mempunyai nilai ekonomi tinggi dan memiliki pertumbuhan yang relatif cepat. Tambak sebagai salah satu media pembudidayaan udang yang paling umum diterapkan. Kualitas air yang baik menjadi kunci dalam budidaya udang vaname. Suhu, $\mathrm{pH}$, dan ketinggian air merupakan parameter penting yang perlu dikontrol secara berkala dan rutin. Kurang terkontrolnya perubahan kualitas air menjadi salah satu penyebab banyak udang yang stres dan mati. Namun pemantauan kondisi air tambak masih dilakukan secara manual dan tidak dilakukan secara intens. Dengan memanfaatkan teknologi Internet Of Things maka penulis akan membuat Sistem Monitoring Tambak Udang Vaname Berbasis Smartphone Android Menggunakan NodeMcu Wemos D1 Mini agar dapat memberikan kemudahan pemilik tambak dalam mengontrol kualitas air tambak jika terjadi perubahan secara signifikan sehingga pemantauan bisa di lakukan dari mana saja tanpa harus datang ke lokasi tambak. Sistem yang dibangun menggunakan microcontroller NodeMcu Wemos D1 mini dan menggunakan sensor $\mathrm{pH}$ SEN0161 untuk mengukur kadar pH, sensor suhu DS18B20 untuk mengukur temperatur, dan sensor ultrasonik HC-SR04 untuk mengukur ketinggian air. Selanjutnya data akan dikirim dan di tampilkan di Telegram Messanger. Berdasarkan hasil pengujian sistem yang sudah di implementasikan didapatkan setiap sensor memiliki tingkat akurasi yang cukup baik sehingga sistem memiliki prospek yang besar dan dapat digunakan untuk budidaya udang vaname.
\end{abstract}

Kata Kunci: IoT; Node-Mcu; Wemos D1 mini; Android; Monitoring, Udang Vaname

\section{PENDAHULUAN}

Tambak adalah kolam buatan yang diisi air dan dimanfaatkan sebagai sarana budidaya perairan (akuakultur). Syarat terlaksananya kegiatan budidaya adalah adanya organisme yang dibudidayakan, media hidup organisme, dan wadah/tempat budidaya. Budidaya merupakan salah satu kegiatan dalam meningkatkan produksi perikanan. Metode pembudidayaan yang dilakukan dapat bersifat tradisional, semi intensif, dan intensif.

Udang Vaname dengan nama latin (Litopenaeus Vannamei) adalah jenis udang yang sedang semarak dibudidayakan oleh masyarakat Indonesia. Jenis udang ini berasal dari Pantai Pasifik Barat Amerika Latin, untuk pertama kalinya dikenalkan pada tahun 1970 di Tahiti. Udang Vaname telah diperkenalkan ke benua asia pada tahun 1978-1979, dan diperkenalkan secara komersial di Indonesia pada tahun 2001. Udang Vaname adalah udang introduksi yang secara resmi ditetapkan sebagai salah satu komoditas unggulan perikanan budidaya oleh mentri DKP (Departemen Kelautan dan Perikanan) pada tahun 2001 [1].

Kehadiran udang Vaname tidak hanya menambah pilihan bagi petani akan tetapi juga bisa menopang kebangkitan usaha udang di Indonesia, akan tetapi budidaya udang putih tidak semudah yang dibayangkan. Kegiatan pembesaran menjadi hal penting dalam budidaya udang Vaname karena banyak kegagalan dalam budidaya udang putih yang diakibatkat oleh kelalaian pada proses pembesaran terutama dari manajemen pakan, kualitas air media pemeliharaan, maupun penanganan genetiknya [2]

Permasalahan utama yang sering ditemukan dalam kegagalan produksi udang Vaname adalah buruknya kualitas air selama masa pemeliharaan terutama pada tambak intensif. Pada tebar yang tinggi dan pemberian 
pakan yang banyak dapat menurunkan kondisi kualitas air. Hal ini diakibatkan adanya akumulasi bahan organik, karena udang meretensi protein pakan sekitar $16.3-40.87 \%$ dan sisanya dibuang dalam bentuk ekskresi residu pakan, serta fases oleh karena itu, manajemen dan monitoring kualitas air selama proses pemeliharaan mutlak diperlukan [3].

Selain itu terdapat permasalahan yang lain adalah cara monitoring kualitas air di lakukan secara manual, dengan cara pemilik memantau secara langsung tanpa tahu kualitas pasti air di tambak. Kualitas air menjadi faktor penting dalam hidup dan tumbuhnya benih udang vaname. Kualitas air yang berpengaruh pada tambak udang adalah suhu air, salinitas, $\mathrm{pH}$ air, oksigen terlarut, dan alkalitas. Namun terdapat beberapa kendala dalam melakukan monitoring salah satunya yaitu kendala jarak, dikarenakan lokasi tambak jauh dari pemukiman, sehingga untuk melakukan monitoring di lakukan secara intens setiap harinya.

Berdasarkan permasalahan yang telah di paparkan diatas, maka perlu dibangunya suatu sitem monitoring yang dapat mengatasi permaslahan kualitas air sehingga budidaya udang vaname dapat berjalan dengan baik. Oleh karena itu dibangunlah sistem monitoring yang diharapkan mampu menjembatani permasalahan tersebut yaitu: "Pemanfaatan Teknologi Internet of Things Untuk Monitoring Tambak Udang Vaname Berbasis Smartphone Android Menggunakan NodeMcu Wemos D1 mini”

Adapun tujuan yang akan dicapai pada penelitian ini adalah:

1. Membantu pengelola untuk mengetahui kondisi kualitas air seperti kondisi suhu, $\mathrm{pH}$, dan ketinggian air, sehngga pemilik dapat memantau dari mana saja dengan menggunakan semartphone tanpa perlu datang kelokasi tambak untuk melakukan pengecekan.

2. Sistem dapat membantu dan menjaga tingkat kehidupan dan pertumbuhan udang vaname.

3. Dengan adanya sistem monitoring tambak udang vaname pengelola tambak dapat membandingkan kualitas air tambak dengan ambang batas kualitas air yang baik untuk budidaya udang vaname.
4. Sistem dapat mengirimkan notifikasi kualitas air yang ditujukan ke pengelola melalui Telegram Messanger.

\section{LANDASAN TEORI}

\subsection{Udang Vaname}

Udang vaname (Litopenaeus vannamei) atau dikenal dengan Pasific White Shrimp merupakan jenis udang introduksi yang memiliki nilai ekonomi tinggi karena banyak dikonsumsi bukan hanya skala nasional akan tetapi mampu diekspor hingga kepasar Amerika dan dunia. Udang ini mulai masuk dan dibudidaya di Indonesia pada tahun 2001. Udang ini mulai menjadi alternatif seiring menurunnya tingkat produksi udang windu akibat terserang penyakit virus White Spot Syndrome Virus (WSSV) sehingga pertumbuhannya menjadi terhambat [4].

Udang vaname memilliki pertumbuhan yang relatif lebih cepat, tahan terhadap serangan penyakit, dan memiliki toleransi yang lebih baik dibanding jenis udang yang lainnya. Pertumbuhan udang vaname rata-rata 3 gram/minggu, dapat ditebar dengan kepadatan sampai $150 \mathrm{ekor} / \mathrm{m}^{2}$. Pemberian pakan udang vaname dilakukan 4 kali setiap hari dengan kandungan protein dengan pelet sebesar $30 \%$. Untuk pemeliharaan $\mathrm{pH}$ air menggunakan kapur jika kondisi $\mathrm{pH}$ air naik dan jika kondisi $\mathrm{pH}$ air turun. Untuk mengatur tingkat suhu air pada tambak dengan mengatur ketinggian air tambak.

\subsection{Internet of Things}

Internet of Things (IoT) merupakan sebuah konsep yang bertujuan untuk memperluas manfaat dari konektivitas internet yang tersambung secara terusmenerus. Adapun kemampuan seperti berbagai data remote control, dan termasuk juga pada benda dunia nyata. Bahan pangan, elektronik, peralatan apa saja, koleksi termasuk benda hidup, yang semuanya tersambung ke jaringan local dan global melalui sensor tertanam dan selalu "on" [3].

Interaksi antar manusia dengan mesin sudah sangat biasa sejak zaman dahulu kala. Interaksi antar manusia dengan mesin sudah bisa pula, sejak adanya penemuan teknologi seperti komputer atau gadget devices lain-nya. Namun, menurut analisa McKinsey Global Institute, IoT adalah sebuah teknologi yang memungkinkan kita untuk menghubungkan 
mesin, peralatan, dan benda fisik lain-nya dengan sensor jaringan dan aktuator untuk memperoleh data dan mengelola kinerjanya sendir, sehingga memungkinkan mesin untuk berkolaborasi dan bahkan bertindak berdasrakan informasi baru yang diperoleh secara independen. Sebuah publikasi mengenai IoT menjelaskan bahwa IoT adalah suatu keadaan ketika benda memiliki identitas, bisa beroperasi secra intelijen, dan bisa berkomunikasi dengan sosilal, lingkungan, dan pengguna.

Dapat kitasimpulkan bahwa IoT membuat suatu koneksi antar mesin dengan mesin, sehingga mesin-mesin tersebut dapat berinteraksi dan bekerja secara independen sesuai dengan data yang diperoleh dan diolahnya secra mandiri. Tujuanya adalah untuk membuat manusia berinteraksi dengan benda dengan lebih mudah, bahkan supaya benda juga bisa berkomunikasi dengan benda lain-nya.

\subsection{Telegram}

Dua bersaudara, Nikolai dan Pavel Durov berhasil menciptakan aplikasi Telegram. Keduanya membagi tugas secara adil yakni Nikolai sebegai developer yang menciptakan protokol MTProto sebagai sistem inti Telegram dan Pavel sebagai pemberi fasilitas saudaranya dalam mengembangkan aplikasi Telegram. Peluncuran aplikasi Telegram berlangsung dua kali dengan selang dua bulan antara pengguna iOS dan Android. Untuk iOS, Telegram berhasil dirilis pada 14 Agustus 2013. Sedangkan untuk Android dirilis pada 20 Oktober 2013 [6].

\subsection{Android}

Android merupakan sistem operasi berbasis Linux yang digunakan untuk telpon seluler (mobile), seperti telepon pintar (smartphone) dan komputer tablet (PDA). Android pada mulanya didirikan oleh Andy Rubin, Rich Miner, Nick Sears, dan Chris White pada tahun 2003. Pada tahun 2005, Andy Rubin dan Larry Page melakukan pertemuan di kantor Google. Pertemuan tersebut bukan petemuan pertama, mereka telah berjumpa 3 tahun sebelumnya, ketika Andy rubin telah merilis smartphone yang dibuatnya. Smartphone tersebut diberi nama "Sidekick" yang memakai sistem pencari default Google. Google meminang Android pada bulan juli 2005, diestimasi harganya sekitar USD 50. Untuk mengembangkan Android, dibentuk OHA (Open Handset Aliance), konsorsium dari 34 perusahaan hardware (peranti keras), software (perangkat lunak), dan telekomunikasi, termasuk Google, HTC, Pada tanggal 5 November 2007, Android dirilis pertama kali Android bersama OHA menyatakan mendukung pengembangan open source pada perangkat mobile [6].

\subsection{Wemos D1 mini}

Mikrokontroler wemos adalah sebuah mikrokontroler pengembangan berbasis modul mikrokontroler ESP8266 yang memilki kemampuan-nya untuk menyediakan fasilitas koneksi $\mathrm{Wi}-\mathrm{Fi}$ dengan mudah serta memori yang digunakan sangat besar yaitu $4 \mathrm{MB}$. pada mikrokontroler wemos memiliki 2 buah chipset yang digunakan sebagai otak kerja platform tersebut yaitu chipset ESP8266 dan chipset $\mathrm{CH} 340$. Wemos D1 mini merupakan modul development board Wi-Fi ESP8266 yang dapat diprogram via Arduino IDE. Kelebihan Wemos D1 mini dengan development board ESP8266 yang lain yaitu adanya berbagai dukungan Shield wemos [4]

\subsection{Sensor pH SEN0161}

Sensor pH SEN0161 adalah sebuah sensor yang dapat mengukur tingkat keasaman dan kebasaan suatu larutan. Prinsip kerja utama $\mathrm{pH}$ meter adalah terletak pada sensor probe berupa elektroda kaca (glass electrode) dengan cara mengukur jumlah ion $\mathrm{H} 3 \mathrm{O}+$ di dalam larutan. Ujungnya ontrol kaca adalah lapisan kaca setebal $0.1 \mathrm{~mm}$ yang berbentuk bulat (bulb). Bulb ini dipasangkan dengan silinder kaca non-konduktor atau plastic memanjang, yang selanjutnya diisi dengan larutan HCL (Hydrogen Chloride) (0.1 $\mathrm{mol} / \mathrm{dm}^{3}$ ). Di dalam larutan HCL terendam sebuah kawat electrode panjang berbahan perak yang pada permukaannya terbentuk senyawa setimbang $\mathrm{AgCl}$ (Argentum Cloride). Konstantanya jumlah larutan $\mathrm{HCL}$ pada system ini membuat electrode $\mathrm{Ag} / \mathrm{AgCl}$ memiliki nilai potensial stabil [3].

\subsection{Sensor Suhu DS18B20}

Sensor suhu DS18B20 adalah suatu komponen yang dapat mengubah besaran panas menjadi besaran listrik sehingga dapat mendeteksi gejala suhu pada obyek tertentu. 
Sensor suhu melakukan pengukuran terhadap jumlah energi panas /dingin yang dihasilkan oleh suatu obyek sehingga memungkinkan kita untuk mengetahui atau mendeteksi gejala perubahan-perubahan suhu tersebut dalam bentuk output analog maupun digital. Sensor ini bekerja dengan protokol komunikasi satu kabel / one wire dan mempunyai kemampuan untuk mendeteksi suhu dari -10 sampai +85 derajat Celsius. [3].

\subsection{Sensor Ultrasonik HC-SR04}

Sensor ultrasonik adalah sensor yang bekerja berdasarkan prinsip pantulan gelombang suara dan digunakan untuk mendeteksi keberadaan suatu objek tertentu didepan-nya, frekuensi kerjanya pada daerah diatas gelombang suara dari $40 \mathrm{KHz}$ hingga $400 \mathrm{KHz}$. Sensor ultrasonik terdiri dari dua unit, yaitu unit pemancar dan unit penerima. HC-SR04 merupakan sensor ultrasonik yang dapat digunakan untuk mengukur jarak antara penghalang dan sensor. Komponen utama penyusunya yaitu ultrasonic transmitter dan ultrasonic receiver. Fungsi dari ultrasonic transmitter adalah memancarkan gelombang ultrasonik dengan frekuensi $40 \mathrm{KHz}$ kemudian ultrasonic receiver menangkap hasil pantulan gelombang ultrasonik yang mengenai suatu objek. waktu tempuh gelombang ultrasonik dari pemancar hingga sampai ke penerima sebanding dengan 2 kali jarak antara sensor dan bidang pantul. Berikut bentuk gambar sensor ultrasonik HC-SR04 [3].

\subsection{Relay}

Relay merupakan jenis golongan saklar yang dimana beroperasi berdasarkan prinsip elektromagnetik yang dimanfaatkan untuk menggerakan konektor guna menyambungkan rangkaian secara tidak langsung. Tertutupnya dan terbukanya konektor disebabkan oleh adanya efek induksi magnet yang diihasilkan dari kumparan induktor yang dialiri arus listrik. Perbedaan dengan saklar yaitu pergerakan konektor pada saklar untuk kondisi on atau off dilakukan manual tanpa perlu arus listrik sedangkan relay membutuhkan arus listrik [11].

\subsection{Pompa Air}

Pompa adalah mesin atau peralatan mekanis yang digunakan untuk menaikan cairan dari dataran rendah ke dataran tinggi atau untuk mengalirkan cairan dari daerah bertekanan rendah ke daerah yang bertekanan tinggi. Prinsip kerja pompa adalah dengan melakukan penekanan dan penghisapan terhadap fluida. Pada sisi hisap pompa (suction) elemen pompa akan menurunkan tekanan dalam ruang pompa sehingga akan terjadi perbedaan tekanan antara permukaan fluida yang dihisap dengan ruang pompa [12]

\section{PERANCANGAN ALAT}

\subsection{Perancangan Keseluruhan}

Perancangan Keseluruhan meliputi perancangan bagian-bagian rangkaian dalam pembuatan keseluruhan alat yang digunakan dalam penelitian ini seperti perancangan desain sensor, desain relay, dan pompa. Rangkaian ini dilakukan setelah masingmasing blok sistem selesai dirangkai.

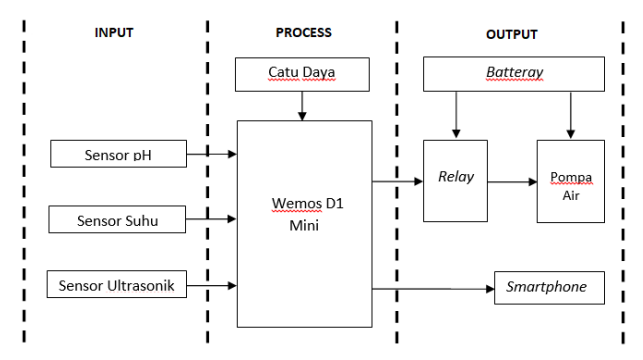

Gambar 1 Blok Diagram Sistem

\subsection{Cara Kerja Alat}

Cara kerja dari sistem monitoring tambak udang vaname ini adalah sebagai berikut:

1. Alat diaktifkan dengan cara memberikan teangan dari power bank ke Wemos d1 mini dengan menggunakan kabel data.

2. NodeMcu akan membaca perintah yang diintruksikan dari Telegram.

3. Sensor akan membaca perintah dari NodeMcu dan akan membaca kondisi air.

4. Setelah masing-masing sensor berhasil membaca kondisi air selanjutnya data akan di kirim oleh NodeMcu ke Telegram.

5. Telegram akan menampilkan hasil pengukuran air.

6. Untuk menghidupkan pompa air digunakan perintah "on pompa" pada Telegram maka perintah tersebut akan di baca oleh NodeMcu dan NodeMcu akan memberi intruksi ke relay. Secara otomatis akan mengirimkan sinyal. Ketika relay pada kondisi high maka listrik akan mengalir ke pompa air dan pompa air akan hidup. Pada saat kondisi Low aliran listrik 
ke pompa akan terputus dan pompa air akan mati.

\section{PENGUJIAN DAN ANALISA}

Pengujian dilakukan bertujuan untuk mengetahui kinerja dan kemampuan dari perangkat yang dibangun. Pengujian dilakukan pada masing-masing subsistem dari perangkat, sehingga dapat dianalisa dan disimpulkan apakah perangkat sudah sesuai dengan yang diharapkan.

\subsection{Pengujian Input}

Pada tahap pengujian input ini terdiri dari pengujian catu daya, sensor $\mathrm{pH}$, sensor suhu, sensor ultrasonik. Hasil dari pengukuran yang didapat dari setiap sensor akan dibandingkan dengan hasil pengukuran dengan alat manual.

\subsubsection{Pengujian Catu Daya}

Pengujian dilakukan dengan memberikan tegangan pada NodeMcu Wemos D1 mini dengan menggunakan powerbank.

Hasil pengujian dapat dilihat pada table berikut:

Tabel 1 Hasil Pengujian Catu Daya

\begin{tabular}{|c|c|c|c|}
\hline $\begin{array}{c}\text { Output } \\
\text { Catu Daya }\end{array}$ & $\begin{array}{c}\text { Input } \\
\text { NodeMcu }\end{array}$ & $\begin{array}{l}\text { Perhitungan } \\
\text { Rata-Rata }\end{array}$ & Keterangan \\
\hline $5 \mathrm{~V} / 1 \mathrm{~A}$ & $5 \mathrm{~V}$ & $4.90 \mathrm{~V}$ & $\begin{array}{l}\text { Terhubung ke NodeMcu tapi } \\
\text { sensor tidak jalan } \\
\text { Terhubung ke NodeMcu }\end{array}$ \\
\hline $5 \mathrm{~V} / 2.1 \mathrm{~A}$ & $5 \mathrm{~V}$ & $4.87 \mathrm{~V}$ & dan sensor berjalan lancar \\
\hline
\end{tabular}

Dari hasil pengujian tersebut catu daya / powerbank dapat memberikan tegangan ke NodeMcu Wemos D1 mini. Hasil pengujian Output catu daya sebesar 5V/2.1A dapat bekerja dengan baik, NodeMcu dan sensor dapat berfungsi normal. Hasil pengujian Output 5V/1A NodeMcu dapat terhubung dengan baik akan tetapi sensor tidak dapat bekerja.

\subsubsection{Pengujian Sensor pH SEN0161}

Pengujian sensor $\mathrm{pH}$ SEN0161 ini dilakukan dengan cara membandingkan nilai yang diterima dari sensor dengan alat $\mathrm{pH}$ meter. Hasil pengukuran dapat dilihat pada tabel berikut:
Tabel 2 Hasil Pengujian Sensor pH SEN0161

\begin{tabular}{lccc}
\hline Larutan & $\begin{array}{c}\text { Alat ukur } \\
\text { manual pH }\end{array}$ & $\begin{array}{c}\text { Sensor pH } \\
\text { meter }\end{array}$ & Error \\
\hline Asam & 4.50 & 4.10 & 0.4 \\
Netral & 7.30 & 7.11 & 0.19 \\
Basa & 7.70 & 7.68 & 0.02 \\
\hline
\end{tabular}

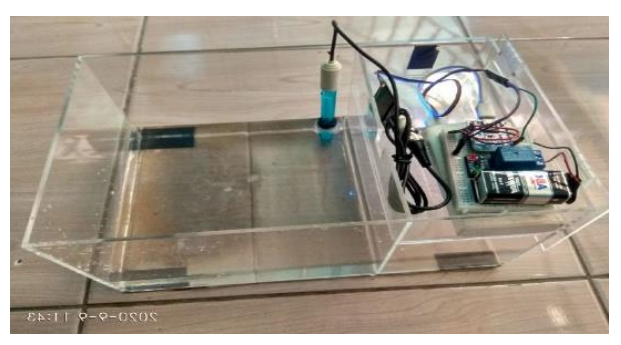

Gambar 2 Pengujian Sensor pH

Pengujian sensor pH SEN0161, sensor ditempatkan pada wadah yang sudah dibuat. Pengujian dilakukan dengan menggunakan tiga jenis larutan buffer yang berbeda yaitu larutan asam, larutan netral, dan larutan basa.

\subsubsection{Pengujian Sensor DS18B20}

Pengujian Sensor DS18B20 ini dilakukan dengan cara membandingkan nilai yang diterima dari sensor dengan alat thermometer suhu air. Hasil pengukuran dapat dilihat pada tabel berikut:

Tabel 3 Hasil Pengujian Sensor Suhu

\begin{tabular}{cccc}
\hline No & $\begin{array}{c}\text { Alat Ukur } \\
\text { Thermo 300 }\end{array}$ & $\begin{array}{c}\text { Sensor Suhu } \\
\text { DS18B20 }\end{array}$ & Error \\
\hline 1 & 25.30 & 25.06 & 0.24 \\
2 & 50.30 & 49.56 & 0.47 \\
3 & 42.00 & 41.13 & 0.87 \\
4 & 47.10 & 46.50 & 0.6 \\
5 & 49.30 & 48.81 & 0.49 \\
\hline
\end{tabular}

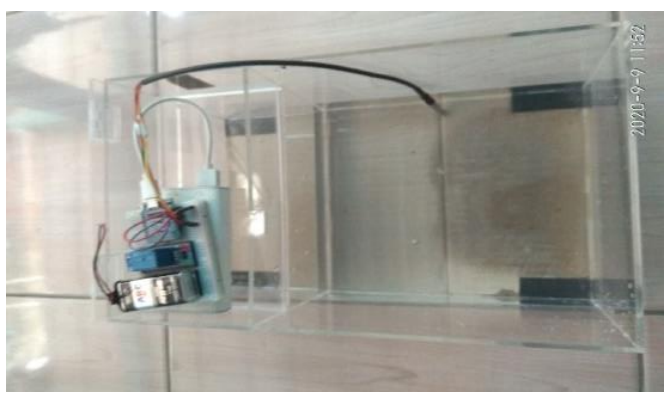

Gambar 3 Hasil Pengujian Sensor Suhu

Pada pengujian Sensor DS18B20, sensor ditempatkan pada wadah yang sudah dibuat, 
kemudian akan diisikan air dengan berbagai suhu.

\subsubsection{Pengujian Sensor Ultrasonik HC- SR04}

Pengujian sensor ultrasonik inidilakukan dengan cara membandingkan nilai yang diterima dari sensor dengan alat pengukur tinggi air konvensional. Hasil pengukuran dapat dilihat pada tabel berikut:

Tabel 4 Hasil Pengujian Sensor Ultrasonik

\begin{tabular}{cccc}
\hline No & Alat Ukur Penggaris & Sensor Ultrasonik & Error \\
\hline 1 & 10.00 & 10.00 & 0 \\
2 & 5.00 & 6.00 & 1 \\
3 & 8.00 & 9.00 & 1 \\
4 & 4.00 & 5.00 & 1 \\
5 & 3.00 & 4.00 & 1 \\
\hline
\end{tabular}

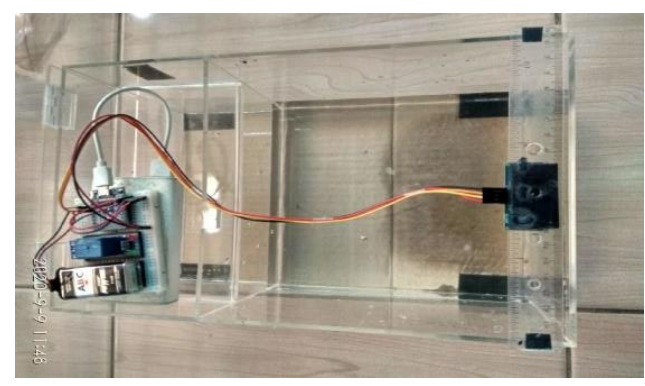

Gambar 4 Pengujian Sensor Ultrasonik

Pada pengujian sensor ultrasonik, sensor ditempatkan diatas wadah yang sudah dibuat, kemudian wadah akan diisikan air dengan tinngkat level ketinggian yang berbeda.

\subsection{Pengujian proses}

Pengujian proses dilakukan dari awal menyalakan alat sampai ke proses sebelum pengujian output. setelah catu daya siap dan alat siap diuji maka program dapat dijalankan dan akan mengeksekusi perintah-perintah di dalamnya. Setelah semua terinisialisasi, maka alat siap diuji. Selanjutnya pengujian sensor $\mathrm{pH}$, Suhu, dan Ultrasonik. Data masuk melalui serial port NodeMcu kemudian data diproses.

\subsection{Pengujian Output}

Hasil dari pengujian output terdiri dari pengujian pompa air dan perencanaan pendukung output. Pada proses ini merupakan pengujian terakhir dari sistem monitoring tambak udang vaname ini. Pengujian output yang dilakukan meliputi:

\subsubsection{Hasil Pengujian Pompa Air}

Pengujian ini dilakukan untuk mengetahui apakah pompa air dapat berfungsi atau tidak pada saat relay mendapatkan intruksi untuk membuka switch, dan terhubung dengan sumber listrik dan mengalirkan arus listrik ke pompa.

Tabel 5 Hasil Pengujian Pompa Air

\begin{tabular}{ccc}
\hline $\begin{array}{c}\text { Pengujian Pompa } \\
\text { Air }\end{array}$ & $\begin{array}{c}\text { Hasil Yang } \\
\text { Diharapkan }\end{array}$ & Hasil Pengujian \\
\hline Relay diberikan & $\begin{array}{c}\text { Pompa dapat bekerja } \\
\text { dan dapat berfungsi }\end{array}$ & Sukses \\
intruksi on & dengan baik & \\
& Pompa mati & Sukses \\
Relay diberikan & & \\
intruksi off & & \\
\hline
\end{tabular}

Hasil dari pengujian yang ditunjukan pada tabel diatas menjelaskan bahwa pompa berfungsi dengan baik pada saat relay dihubungkan dengan tegangan dan diberi intruksi.

\subsubsection{Pengujian Aplikasi}

Pengujian aplikasi pada penelitian ini dilakukan oleh user atau pengguna, sedangkan metode pengujian yang digunakan adalah metode black box. Pengujian aplikasi merupakan pengujian tahap akhir dari sistem monitoring tambak udang vaname. Metode ini digunakan untuk mengetahui apakah perangkat lunak berfungsi dengan benar.

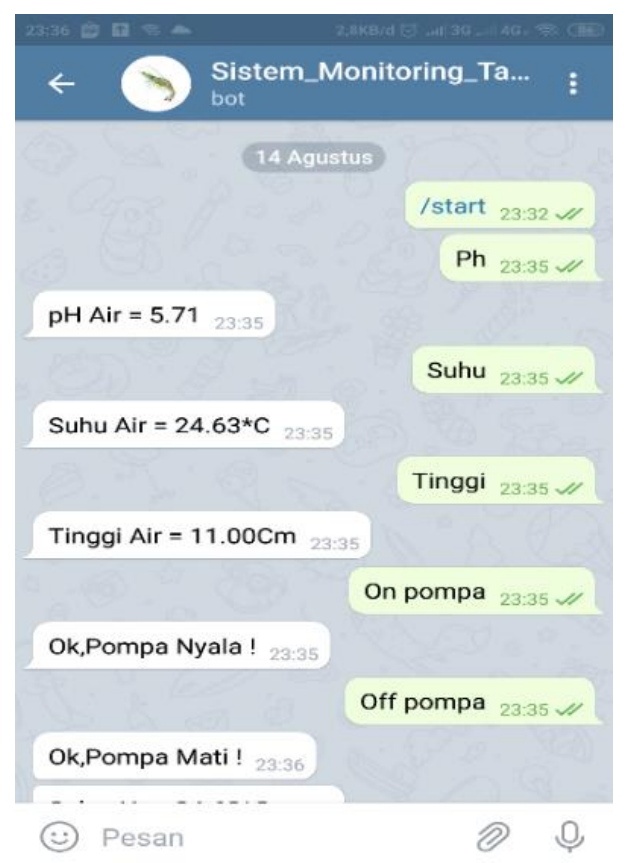

Gambar 5 Pengujian Aplikasi Telegram 


\subsection{Analisa Hasil}

Setelah seluruh prosedur pengujian dilakukan maka didapatkan data-data yang dibutuhkan. Hasil yang didapatkan dari pengujian, alat sudah dapat berfungsi dengan baik. Diperoleh data analisa dan hasil pengujian sebagai berikut:

Tabel 6 Analisa Hasil Pengujian

\begin{tabular}{|c|c|c|c|}
\hline $\begin{array}{l}\text { Penguj } \\
\text { ian }\end{array}$ & $\begin{array}{l}\text { Hasil yang } \\
\text { diharapkan }\end{array}$ & $\begin{array}{l}\text { Hasil } \\
\text { Pengujian }\end{array}$ & $\begin{array}{l}\text { Kesim } \\
\text { pulan }\end{array}$ \\
\hline $\begin{array}{l}\text { Catu } \\
\text { Daya }\end{array}$ & $\begin{array}{l}\text { Dapat } \\
\text { terhubung } \\
\text { dengan } \\
\text { NodeMcu }\end{array}$ & $\begin{array}{l}\text { Terhubung } \\
\text { dengan } \\
\text { NodeMcu }\end{array}$ & $\begin{array}{l}\text { Penguji } \\
\text { an } \\
\text { Sukses }\end{array}$ \\
\hline $\begin{array}{l}\text { Sensor } \\
\mathrm{pH}\end{array}$ & $\begin{array}{l}\text { Dapat } \\
\text { mengidentifi }\end{array}$ & $\begin{array}{l}\text { Berhasil } \\
\text { mengidentifi }\end{array}$ & $\begin{array}{l}\text { Penguji } \\
\text { an }\end{array}$ \\
\hline $\begin{array}{l}\text { SEN01 } \\
61\end{array}$ & $\begin{array}{lr}\text { kasi } & \text { kadar } \\
\mathrm{pH} & \text { air } \\
\text { tambak } & \end{array}$ & kasi $\mathrm{pH}$ air & Sukses \\
\hline $\begin{array}{l}\text { Sensor } \\
\text { Suhu }\end{array}$ & $\begin{array}{l}\text { Dapat } \\
\text { mengidentifi }\end{array}$ & $\begin{array}{l}\text { Berhasil } \\
\text { mengidentifi }\end{array}$ & $\begin{array}{l}\text { Penguji } \\
\text { an }\end{array}$ \\
\hline $\begin{array}{l}\text { DS18B } \\
20\end{array}$ & $\begin{array}{l}\text { kasi suhu air } \\
\text { tambak }\end{array}$ & $\begin{array}{l}\text { kasi suhu air } \\
\text { tambak }\end{array}$ & Sukses \\
\hline $\begin{array}{l}\text { Sensor } \\
\text { Ultraso }\end{array}$ & $\begin{array}{l}\text { Dapat } \\
\text { mengukur }\end{array}$ & $\begin{array}{l}\text { Berhasil } \\
\text { mengukur }\end{array}$ & $\begin{array}{l}\text { Penguji } \\
\text { an }\end{array}$ \\
\hline & $\begin{array}{l}\text { ketinggian } \\
\text { air }\end{array}$ & $\begin{array}{l}\text { ketinggian } \\
\text { air }\end{array}$ & Sukses \\
\hline $\begin{array}{l}\text { Pompa } \\
\text { air }\end{array}$ & $\begin{array}{l}\text { Pompa } \\
\text { Dapat } \\
\text { beroprasi } \\
\text { dan } \\
\text { berfungsi } \\
\text { denganbaik }\end{array}$ & $\begin{array}{l}\text { Pompa dapat } \\
\text { beroperasi }\end{array}$ & $\begin{array}{l}\text { Penguji } \\
\text { an } \\
\text { Sukses }\end{array}$ \\
\hline $\begin{array}{l}\text { Telegra } \\
\mathrm{m}\end{array}$ & $\begin{array}{l}\text { Mampu } \\
\text { berinteraksi } \\
\text { dengan } \\
\text { mikrokontrol } \\
\text { er wemos d1 } \\
\text { mini }\end{array}$ & $\begin{array}{l}\text { Berhasil } \\
\text { memonitorin } \\
\mathrm{g} \text { pH, suhu, } \\
\text { ketinggian } \\
\text { air, dan dapat } \\
\text { menghidupk } \\
\text { an/mematika } \\
\mathrm{n} \text { pompa } \\
\text { melalui } \\
\text { telegram }\end{array}$ & $\begin{array}{l}\text { Penguji } \\
\text { an } \\
\text { Sukses }\end{array}$ \\
\hline
\end{tabular}

\section{KESIMPULAN DAN SARAN}

\subsection{Kesimpulan}

Berdasarkan penelitian yang telah dilakukan, maka dapat disimpulkan sebagai berikut:

1. Berdasarkan hasil pengujian, sistem mampu membantu pemilik dalam melakukan monitoring kualitas air seperti: $\mathrm{pH}$, suhu, dan ketinggian air.

2. Hasil monitoring dapat dikirim ke Aplikasi Telegram sesuai dengan yang diharapkan.

3. Berdasarkan hasil pengujian, penggunaan sensor $\mathrm{pH}$ SEN0161 untuk mengukur $\mathrm{pH}$ air harus dilakukan kalibrasi secara berkala untuk mendapatkan hasil pengukuran yang akurat.

4. Dengan adanya hasil penelitian ini telah dihasilkan alat sistem monitoring tambak udang vaname dengan memanfaatkan teknologi internet of things.

\subsection{Saran}

1. Menambahkan parameter utama yang lain seperti menghitung kadar oksigen terlarut, menghitung salinitas (tingkat kadar asin air), dan menghitung tingkat kekeruhan pada air tambak

2. dikarenakan sensor $\mathrm{pH}$ memiliki kelemahan, maka perlu menggunakan sensor $\mathrm{pH}$ lain untuk mendapatkan pengukuran yang akurat dan praktis.

3. Perlu dilakukan penelitian lebih lanjut untuk mengembangkan bentuk rancangan sensor yang lebih baik lagi agar layak digunakan oleh pengguna.

\section{DAFTAR PUSTAKA}

[1] T. Lin, "Udang Vannamei," 2462015. [Online]. Available: https://www.kompasiana.com/tan-tjuenlin/54f7cc8da333118d508b4673/udangvannamei.

[2] N. Nihayati.Dkk, "Praktikum Budidaya Perairan Bahari Tentang Tambak Udang Vannamei (Litopeneaus Vannamei)," 2015.

[3] M. Faruq, "Sistem Monitoring Kualitas Air Pada Tambak Udang Vaname Di Kecamatan Tirtayasa Berbasis Internet of Things," 2019.

[4] M. W. Alfiansyah, "Implementasi IoT Untuk Early Warning System (EWS) Pada Tambak Udang Vaname," Publikasi Tugas Akhir S-1 PSTI FT-UNRAM, p. 8, 2020.

[5] G. Prakoso, "Rancang Bangun Kontrol dan Monitoring Kualitas Air Tambak Udang Menggunakan Android," 2019. 